\title{
Malacca Mosque: The Aesthetics of Old Mosques in Malaysia
}

\author{
Nor Afian Yusof \\ Pusat Citra Universiti, Universiti Kebangsaan Malaysia, 43600 Bangi, Selangor, Malaysia \\ Email: affian@ukm.edu.my \\ Hamdzun Haron \\ Pusat Citra Universiti, Universiti Kebangsaan Malaysia, 43600 Bangi, Selangor, Malaysia \\ Email:hh@ukm.edu.my \\ Narimah Abd. Mutalib \\ Bukit Changgang Primary School, 42700 Banting, Selangor, Malaysia \\ Email: neryzone@yahoo.com
}

\section{Doi:10.5901/mjss.2014.v5n27p1342}

\begin{abstract}
The old mosques in Malacca are the historical monuments or historical remains that are highly valuable to the development and Islamic civilization in Malaysia. The construction of the old mosques in Malacca around the 18th century represents the greatness of Islam in the state. In fact according to historical records, Malacca was once the most prominent center for dissemination of Islam in Southeast Asia that was formerly known as the 'Nusantara'. These old mosques had left behind unique aesthetics values, the result of cultural mixing occurred more than 300 years ago. Descriptive study was carried out in order to appreciate the aesthetics found in these old mosques. The study will focus on three of the oldest mosques in Malacca namely Tengkera Mosque, Kampung Hulu Mosque and Kampung Keling Mosque. Aesthetics appreciation is more towards the architecture, the art of carving/engraving and calligraphy art found in the three mosques.
\end{abstract}

Keywords: Aesthetics value, history, Malacca, mosque, Islamic civilization;

\section{Introduction}

Descriptive study was conducted on the three old mosques that often become the attention and subject of historical study. The three mosques are Kampung Hulu Mosque, Kampung Keling Mosque and Tengkera Mosque, located in the district of Melaka Tengah. Rationale for the three selected mosque was based on two factors; first, the three mosques are among the oldest mosques in Malacca and second, the originality and design history of these mosques are still intact despite undergoing several transformation and reconstruction.

Looking back at the history, Malacca was known as the most prominent center for dissemination of Islam in the archipelago known as Southeast Asia (Buyong Adil, 1973). This statement is further strengthened by a statement of Mohd Jamil Mukmin (2004). Malacca was not only the center for dissemination of Islam but a center of Islamic civilization as well, after Pasai and Aceh kingdom in Indonesia. This has been proven by historical findings within the country and abroad. Among the major historical legacy we can see today is the old mosques still standing as a prove that Malacca in the past was indeed a center for dissemination of Islam in Southeast Asia. Until today, Malacca has more than 54 ancient mosques aged more than 100 years old and has been gazetted as heritage building by the state government (http://www.al-azim.com).

Although these mosques were built during the Dutch colonial period around year 1700 and not during Malacca Malay Sultanate era, it still proves that Malacca was once a center for dissemination of Islam. Portuguese colonialism in 1511 on Malacca caused many non-Christian places of worship including mosques were destroyed. Among them was the first mosque built in Malacca that was said located adjacent to the historic monument Stadhuys (Ed. Martin Frishman and Hasan-Uddin Khan, 1994).

According to Ed. Martin and Hasan-Uddin Khan, these mosques have been rebuilt in the Dutch colonial period around year 1700 . This was due to policy changes by Dutch government that practicing religious diversity. Based on this, 
the Dutch ruler, better known as the Dutch East India Company (VOC) had financed the construction of mosques built by local people at the time. What we see today is a historical monument of nearly 300 years old and still contributing the role as the oldest worship place for Muslim in the state of Malacca.

\section{Malacca Today}

Malacca is a state located on the west coast of Peninsular Malaysia, bordering Johor to the south and Negeri Sembilan to the north. The state is divided into three districts, namely Melaka Tengah, Jasin and Alor Gajah. In total, Malacca is an area of 1650 square kilometers with a population of 738,800 .

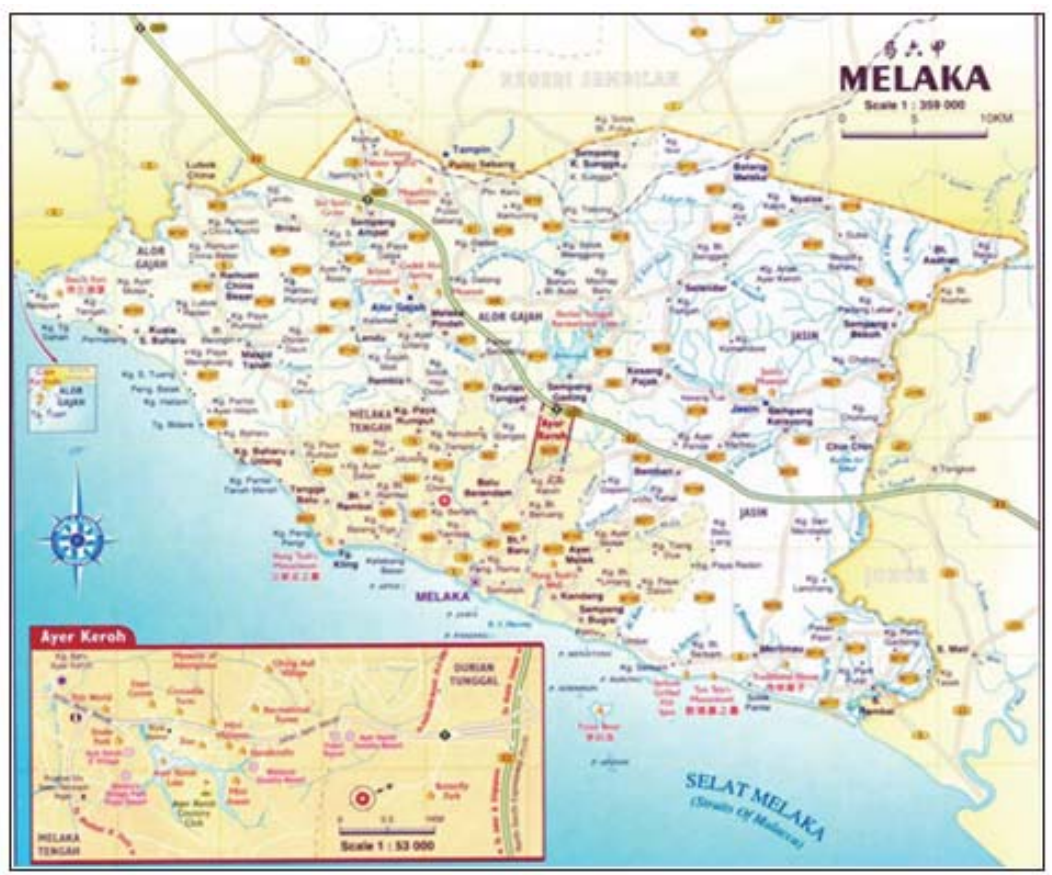

Visual 1: Map of Malacca

Malacca today is a relatively fast-growing state and known as historic state that is rich with culture diversity. Thus tourism and manufacturing sectors plays the role as major economy catalyst for Malacca with slogan 'Visit Historic Malacca = Visit Malaysia'. In addition, the greatness of Malacca as a historic state has been recognized by the world when the state was selected as twin cities to five other cities namely Lisbon in Portugal, Kuala Lumpur in Malaysia, Hoorn in the Netherlands, Valparaiso in Chile and Nanjing in China.

On August 1, 2008 the state of Malacca has been recognized by UNESCO (United Nations Educational, Scientific and Cultural Organization) as World Heritage City. With this recognition, it can be said that Malacca, the city with diverse world heritage trails is on par with other World Heritage Cities namely Croatia, France, Germany, Italy etc

\section{Aesthetics}

Alexander Gottlieb Baumgarten through his several writings on aesthetics said that aesthetics is a theory used to distinguish the intellectual knowledge and knowledge through senses (Encarta Encylopedia 2001, 1999). For example, if a form has reached the right value, it can be judged by aesthetics. But if the form is exceeding the value it should be, it may be judged as beautiful. Therefore, we can say that something with aesthetics value is not necessarily beautiful.

Nevertheless, many art figures such as Clive Bell, George Santayana and RG Collingwood think that beauty is connected with pleasant feelings (Sutrisno, 1993). It means that if an art object is able to bring pleasant feelings to the observer, then it may be described as 'beautiful'. Hospers (1969) in the other hand said...

"Aesthetics is the branch of philosophy that is concerned with the analysis of concepts and the solutions of problems that arise when one contemplates aesthetic objects. Aesthetic objects, in turn, comprise all the objects of 
aesthetic experience; thus, it is only after aesthetic experience has been sufficiently characterized that one is able to delimit the class of aesthetic objects"

If we refer to the definition of aesthetics by Hospers, it may be said that in order to find aesthetics experience, observers and artists should have the desire to observe, to study the aesthetic objects or even involved in the creation of aesthetic objects together. According to Sustrino (1993), in the study of philosophy, an understanding of aesthetics can be divided into the following two approaches: -

1. Make direct observation to art objects or natural beauty,

2. Experience the beauty of its own.

An art philosopher, Thomas Aquino in his writing about the 'beauty related to knowledge' (http://www.uiah.fi) stated that 'something can be described as beautiful if it is pleasing to the eye of the observer, but the knowledge of beauty experience will actually depends on the observer's real experience'. In general, what Thomas Aquino said is in line with the principles of Aristotle, who stressed the importance of scientific knowledge and experience that occurs in human. Therefore, the observation and theory of aesthetic value in finding the true meaning of beauty may be associated with two methods that is understanding art as an aesthetic object and understanding human being as a subject who observes or creates the aesthetic work.

\section{The History of Kampung Hulu Mosque}

The history of the mosque began when the Dutch ruler with its open policy on religion had financed the construction of this mosque around year 1728. However, some opinionate that the mosque was built in 1720 (www.melayuonline.com). The mosque is located in the centre of Malacca city in the district of Melaka Tengah which is now surrounded by Chinese shops. The mosque was built by Dato' Samsudin bin Arom, an immigrant from China who converted to Islam with helps of local community (Utusan Malaysia, 2006). The original building was later improved by Sheikh Al-Omar Bin Hussain AlAttas. The mosque has been renovated and rebuilt into a concrete building in 1892 to replace the timber building. An article in Utusan Malaysia (2006 ) stated that other than the ruins of A'Famosa, Bastian House and Stadthuys, old mosques in Melaka also attract the attention of tourists from all over the world. The mosques include Kampung Hulu Mosque, Kampung Keling Mosque, Tengkera Mosque, Duyong Mosque, Peringgit Mosque and many other old mosques aged hundreds of years old.

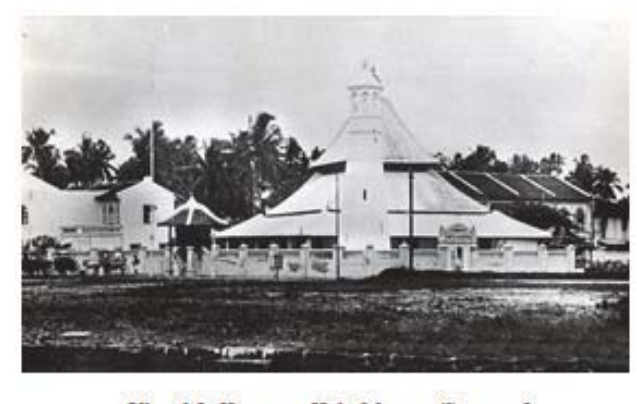

Visual 2: Kampung Hulu Mosque (Source of http:/ uatazazhar com)

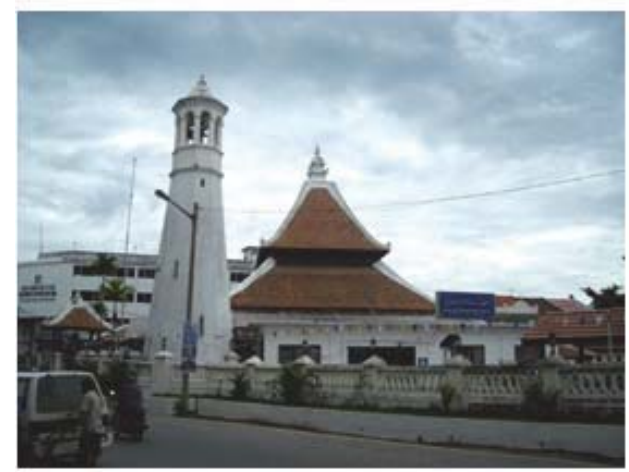

Visual 3: Kampung Hulu Mosque today 


\section{The history of Kampung Keling Mosque}

The construction of the mosque was carried out in 1748 and according to history, the surrounding area of the mosque was formerly inhabited by immigrants nicknamed 'Keling' (from the word kalinga) from southern India. This area is now surrounded by Chinese shops. The mosque is located in Tukang Emas Road which is adjacent to the Hindu temple and a Buddhist temple. The mosque was later modified and renovated into a concrete building in 1872. In 1908, the roof of the mosque was raised similarly to the roof of Kampung Hulu Mosque.

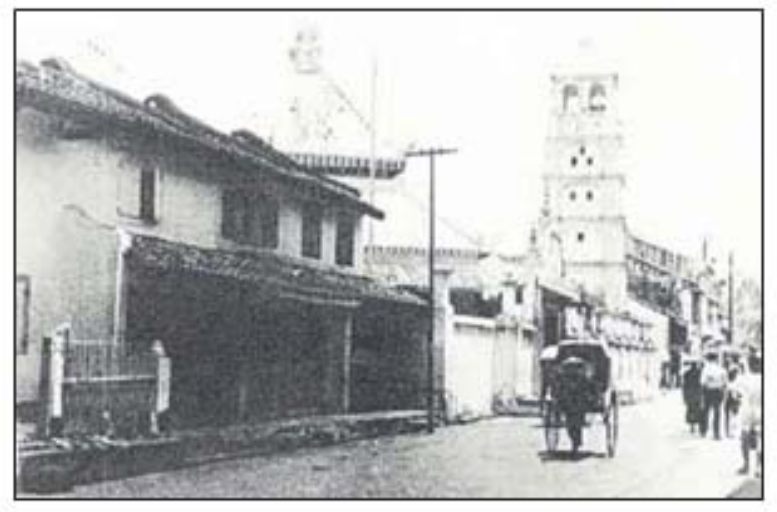

Visual 4: Kampung Keling Mosque. (Source of http://webbiz2u.com/JAM/category/malacca)

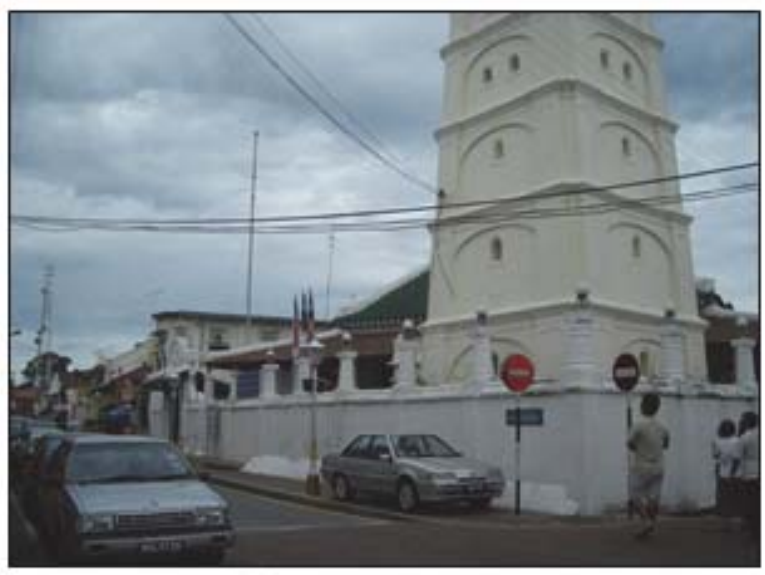

Visual 5: Kampung Keling Mosque now

\section{The history of Tengkera Mosque}

Tengkera Mosque is considered among the oldest mosques in Malacca and was built around 1728 during the Dutch colonial era. The mosque is located in the district of Tengkera. Tengkera Mosque was once the State Mosque of Malacca before the new State Mosque was built in Bukit Palah.

Originally, the mosque was made of timber with the roof made of palm leaves, and pillars from Belian or Ulin wood imported from Kalimantan, Indonesia. The mosque has been renovated twice in 1890 and in 1910. The tomb of Sultan Hussein Mohammed Shah, the Sultan of Johor who recognized the treaty of Singapore made between Sir Stamford Raffles and Temenggong Abdul Rahman on February 6, 1819 is located inside the mosque. The conservation work was done in year 2000 by the Department of Museums and Antiquities. 


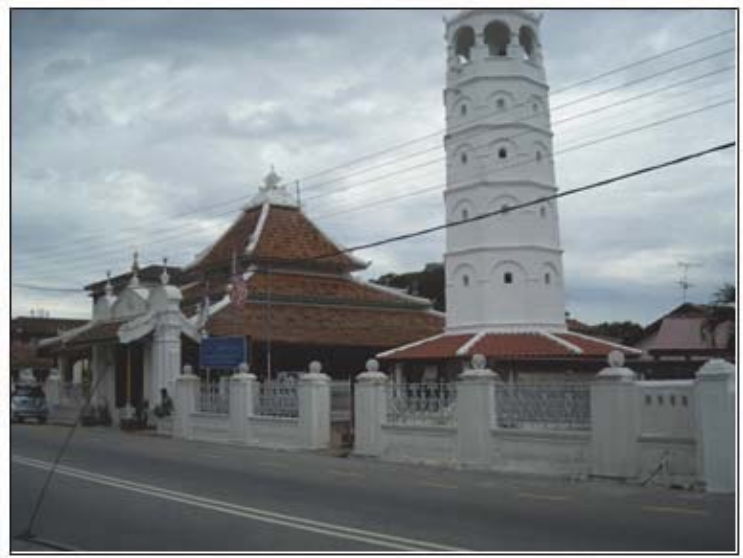

Visual 6: Tengkera Mosque now

\section{The Aesthetics of Kampung Hulu Mosque, Kampung Keling Mosque and Tengkera Mosque}

According to Abdul Halim Nasir (1995), though Islam has developed since the 15th century, the architectural mosque in that era is hardly ever found whether in Malaysia, Indonesia, Thailand, Brunei or Philippine. This is due to mosques and prayer rooms at the time were constructed more like a normal house. In a way, the mosque looks like a house and it is very difficult for us to identify it because the design is different from the mosque design of the Middle East. Furthermore, during the colonial era of Malay-Nusantara, particularly the Portuguese occupation of Malacca in 1511, many houses cum mosques were destroyed and burnt down. Albuquerque report mentions a huge mosque located on the foothill of St. Paul at the riverbank of Malacca (document 1511.27) but not mentioning the architecture of the mosque which was then destroyed by them. The bricks of the mosque were later built into a church on the site of the demolished palace of Sultan of Malacca. The architecture of old mosques in Malacca is very beautiful, unique and classic and still standing to this day. The most unique architectural features of the mosque in the state is characterized by a uniform structure that looks almost similar, although there are differences in design such as in Jasin, Melaka Tengah and Alor Gajah. Based on studies of several researchers from Malacca Museum Corporation (PERZIM), the Malays in the state once had their own philosophical beliefs that each tier of the mosque's roof has a specific meaning and related to one another. They believe that the top tier of the roof means 'human's faith in God', the second tier, 'human to human relationship' and the third tier means 'nature' which links human to the creator. There is an old view stating that the architecture of every mosque in the state had foreign influences brought by traders from India, China and Arab (Utusan Malaysia, 2006).

However, PERZIM denied the theory and defended the authenticity of architecture of the mosques in Malacca. According to General Manager of PERZIM Datuk Dr. Ramlah Adam, the architecture of the mosques in Malacca was designed by Malacca Malay community and has no foreign influences as commonly stated. According to her, Malay community also has many renowned and skillful artisans in local architecture.

She also denied the saying about the architecture of the old mosques in Malacca resembles a pagoda in China or bearing other foreign influences. A study carried out by local researchers found that carvings on the roofs and walls of the mosques that symbolize motifs of nature are indeed genuinely produced by Malay craftsmen. She added that the architecture and carving patterns of the mosques in this state is using only motifs of nature. Plants influence much the main criteria of the architecture and the carvings on the walls and roofs of the mosque. In fact, there are carvings on the roof with motifs of 'sulur bayur', 'mahkota' and 'awan larat' that meets the Malay design elements. Meanwhile, the construction material on the walls of the mosque is believed to be made from a mixture of white egg, sand and granite. One of old mosques that attract tourist's attention is Kampung Hulu Mosque (Utusan Malaysia, 2006).

If we look closely at the plans in visual 7,8 and 9, it is clearly showing the similarity in design concept of the three mosques such as in the triangular roof and in the four main pillars that support the building structure. 


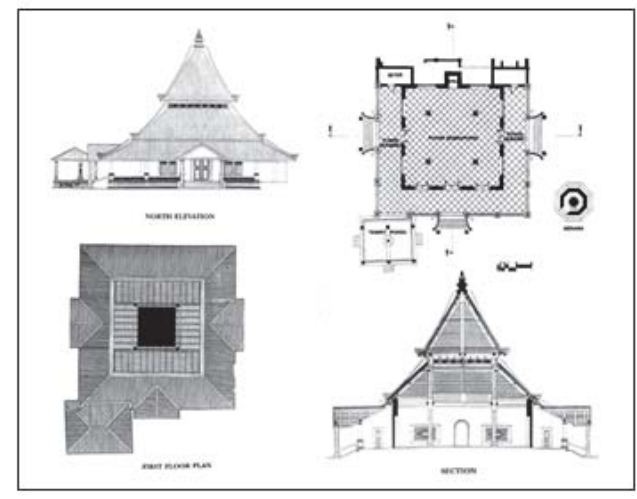

Visual 7: Kampung Hulu Mosque plan, Malacca (Source of Mohamad Tajudin Mohamad Rasdi, 2000. The Architectural Heritage of the Malay World, The Traditional Mosque)

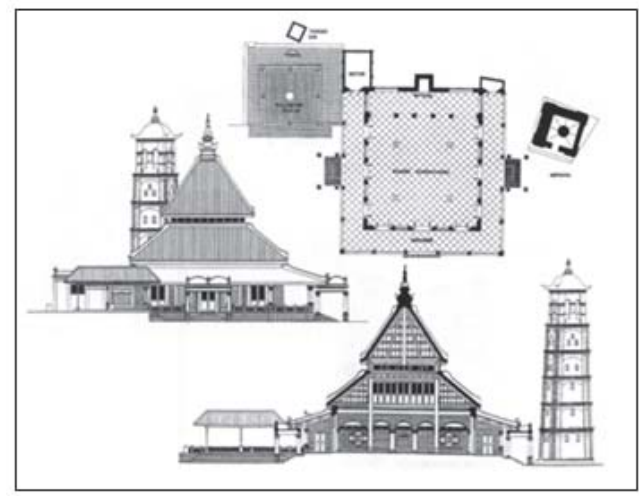

\footnotetext{
Visual 8: Kampung Keling Mosque plan, Malacca (Source of Mohamad Tajudin Mohamad Rasdi, 2000. The Architectural Heritage of the Malay World, The Traditional Mosque)
}

Generally, the architectural structure of the three mosques was based on the famous Malay-Nusantara architecture which used four pillars as the main pillar for the entire mosque. According to Abdul Halim (1995), mosques in the 18th century, particularly Tengkera Mosque, Kampung Keling Mosque and Kampung Hulu Mosque were built on the principles of Malay-Nusantara architecture. It is proven by the usage of Belian or Ulin wood mostly imported from Kalimantan as the main pillar for the roof and said to be as strong as concrete used nowadays.

According to Abdul Halim again, the measurement of the building plans of Tengkera Mosque and Kampung Hulu Mosque is about $18.30 \mathrm{~m} \times 18.30 \mathrm{~m}$, and the measurement from the floor to the top of the roof is about $14.6 \mathrm{~m}$. The mosque has 4 main pillars and 12 verandah pillars. The design pattern of Kampung Keling Mosque was originally similar to Kampung Hulu Mosque before the mosque was being rebuilt into concrete building to replace the timber structure in 1872.

Mohamad Tajuddin (2000) stated that the mosques such as Kampung Hulu Mosque is the best example of a combinational traditional Malay-Chinese architecture. This can be seen through the minaret of the mosque and decorative motifs on the roof that looks similar to the traditional elements of Chinese architecture. The intertwined of the two architecture elements occurs because the artisans were Malays and Chinese. Kampung Hulu Mosque construction was led by a Chinese captain who converted to Islam. This combination had given the unique, diverse and interesting aesthetics to the mosque.

Apart from the architectural aesthetics mentioned earlier, the aesthetic strength of the three mosques lies on the ornate carving, as well as the decorative motifs in the interior and exterior of the mosques. According to Abdul Halim Nasir (1995), the ridge of Tengkera Mosque was decorated similar to the roof of Chinese temple. Visual 11 shows the decorative motifs of the ridge is similar of those seen in Chinese temple. According to history, in early 1910, this mosque had been renovated and the responsible craftsmen who designed the ridge had added the elements of Chinese architecture into it. Nevertheless, the basic construction of these mosques still retains the architecture of MalayNusantara. 
The ridges on the three old mosques in Malacca had been given a touch of Chinese design especially the Tengkera Mosque. This can be seen in visual 12, 13 and 14. However, the uniqueness can be seen through the different designs, patterns and materials of the domes on the roof of the three mosques.

Visual 15 and 16 shows floral pattern so neatly carved displaying the influence of Malay unique carving emphasizes on ornate bas-relief design. Visual 15 shows carved timber pillars, while visual 16 shows floral motifs and ornate design on teak wood door which is so attractive. According to information from several mosque goers, the door was replaced with a new door by Malacca State Government during the renovation carried out not long ago.

Cast iron with floral and ornate design motif adorned each fanlight of the entrance door to Tengkera Mosque as seen in visual 17. From observation, the panel was formed using two separate molds before the pieces were joint together. It was then painted with two different colors to highlight the ornate carving with floral or plants motifs.

Visual 18 shows that the pillar made from Belian wood from Kalimantan, Indonesia was also given a touch of floral motifs carving which was then painted with gold color to give prominence effect to the four pillars. Whilst visual 19, 20 and 21 shows the old but unique rostrum of Tengkera Mosque which is fully adorned with floral motifs carving. The top part of the rostrum also has a similar shape with the roof of the mosque. From closer look, we can clearly see the influences of Chinese element on the rostrum. This rostrum looks like Chinese litter (vehicle) but had been infiltrated by the classic and exotic Malay carving almost on the whole part even though there might be some elements which is somewhat similar to Chinese carving.

The carvings on this rostrum is so impressive and unique. All parts were painted gold with parts of the background painted red and the original color of the timber was brushed with shellac. The overall design is pretty classic and through observation on the other old mosques, the shapes, patterns and styles of the rostrum is almost similar to the one in Tengkera Mosque, the only difference lies in the carving, the size and the design of the rostrum.

Visual 22 shows part of the window is carved with ornate floral motifs incorporating Malay classic elements. Whilst the carving in visual 23 is a rather old and rustic wood carving found mostly inside the mosque.

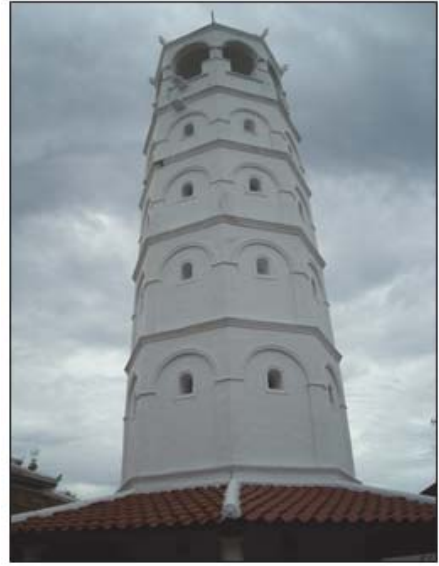

Visual 10: The minaret of Tengkera Mosque was brilt like a tiered pagoda featuring elements of Chinese architectur

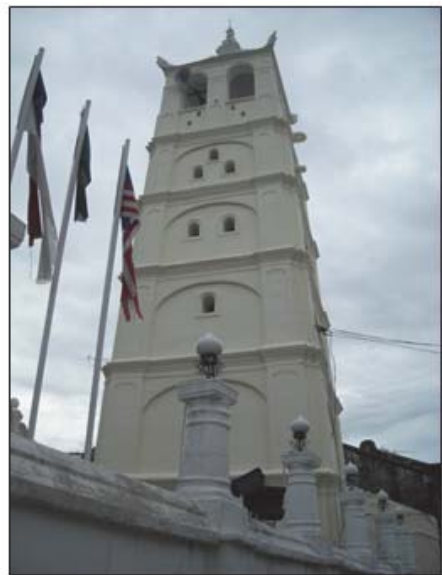

Visual 11: The minaret of Kampung Keling Mosque with a touch of Chinese architecture

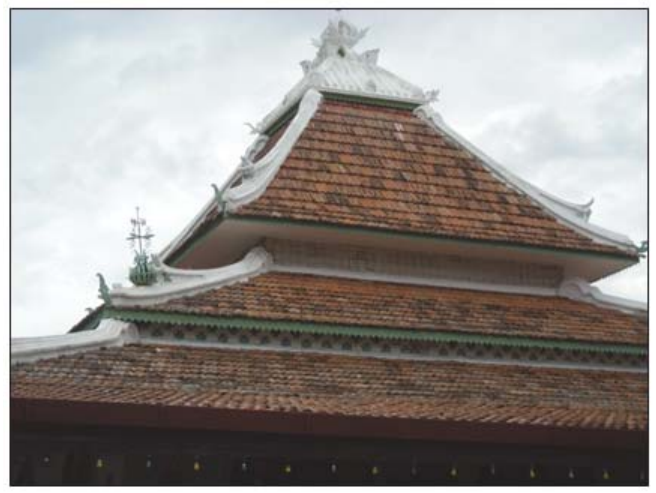

Visual 12: Wary ridge on Tengkera Mosque looks similar to Chinese 


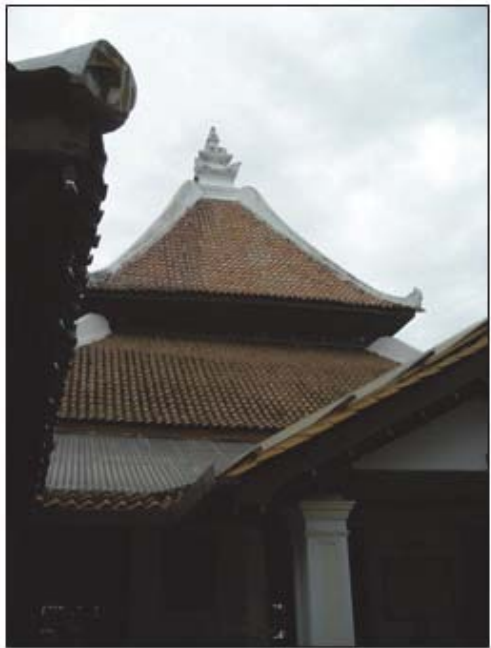

Visual 13: The ridge of Kampung Hulu Mosque with influence of Chinese architecture

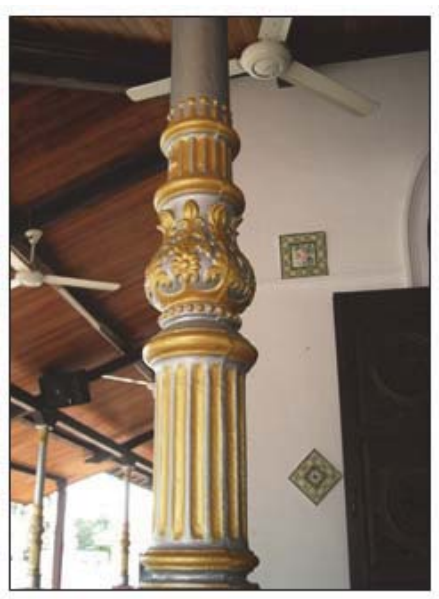

Visual 15: Floral pattern carving on the pillar of Tengkera Mosque

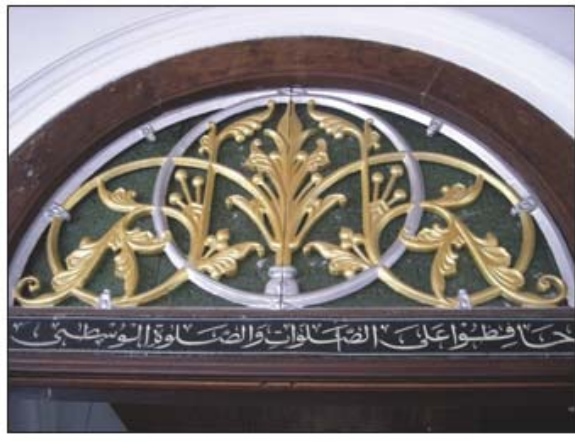

Visual 17: Floral motifs carving adomed the fanlight of the entrance door of the mosque

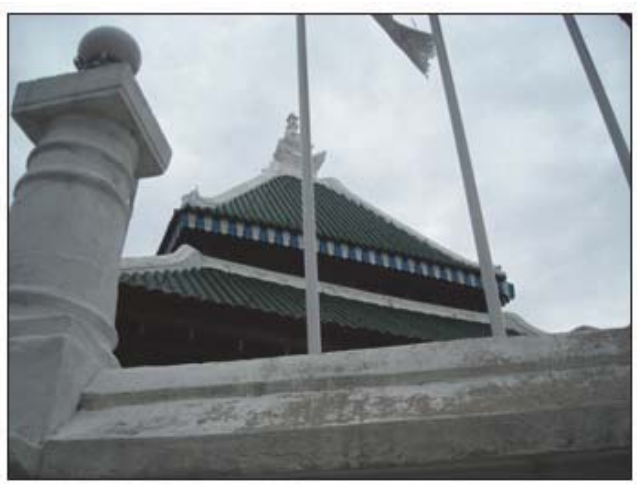

Visual 14: Kampung Keling Mosque roof structure

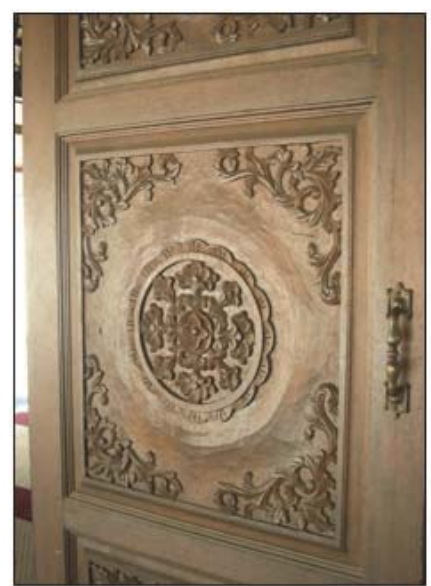

Visual 16: Foral motifs carving on the entrance door of Tengkera Mosque.

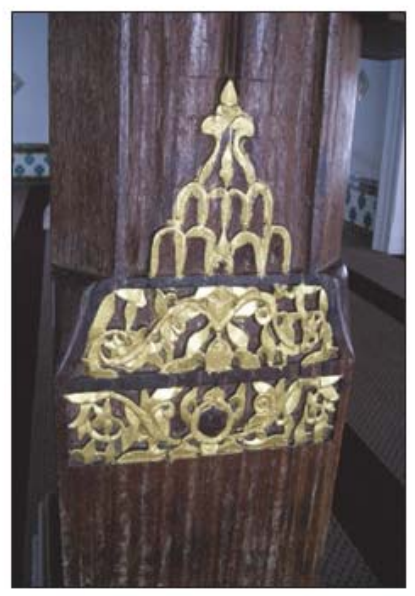

Visual 18: Main pillar carred with floxal motifs 


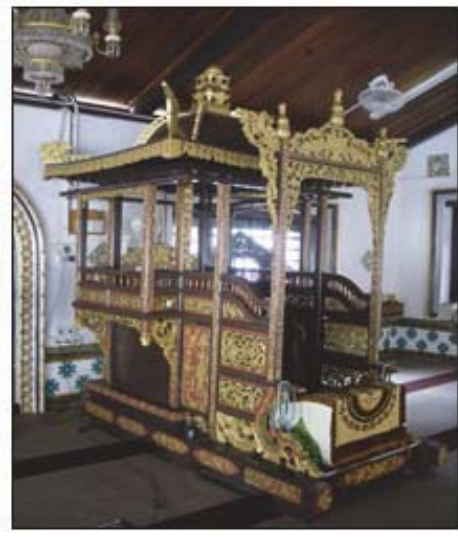

Visual 19: All parts of the rostrum in Tengkera Mosque is adomed with carving

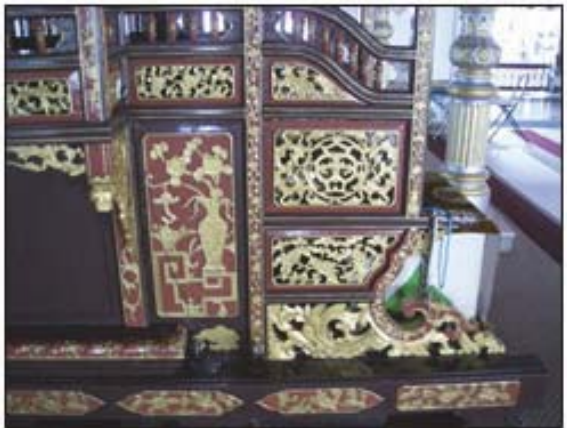

Visual 21: Each comer of the side part is also adomed with carving

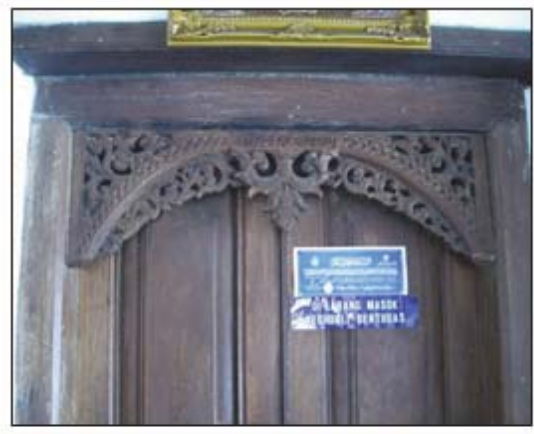

Visual 23: Wood carving on the door frame of the staff's room

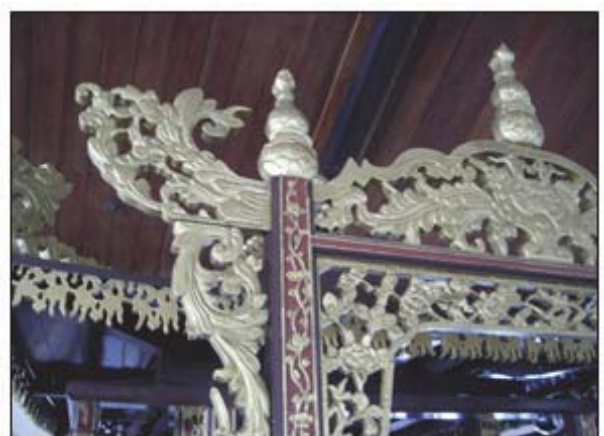

Visual 20: The top of the rostrum is fully carved with floral motifs

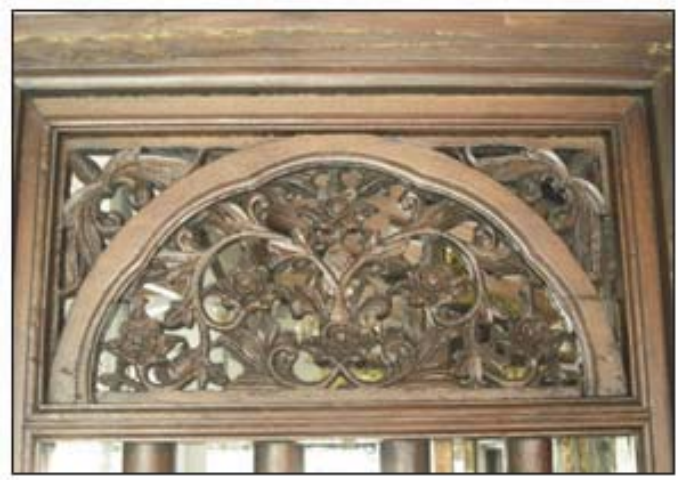

Visual 22: The carving of the window

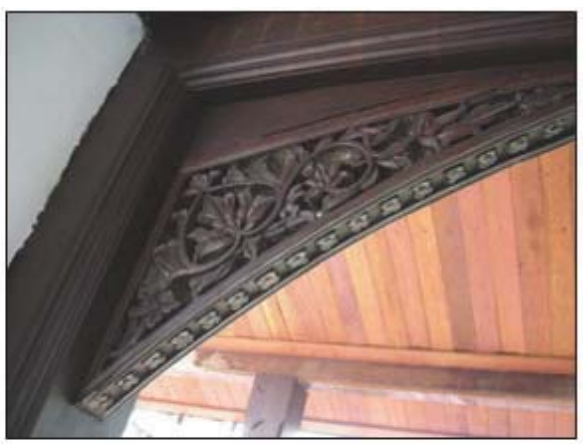

Visual 24: The entrance door is also decorated with exquisite carving

One of the wood carving that is interesting to see can be found on the fanlight of the main entrance door of Tengkera Mosque. It is also decorated with beautiful ornate floral motifs. Undoubtedly, many parts of the mosque were carved with Malay ornate floral motifs. Even the small cast iron fence at the verandah is decorated with floral motifs and the flower petals were painted silver and gold. This can be seen in visual 25.

The next study was on Kampung Hulu Mosque in the heart of Malacca city. The interior design is almost similar to Tengkera Mosque; a significant difference can be seen in the decorative motifs and the interior design methods. As in 
Tengkera Mosque, the rostrum in this mosque is equally impressive with unique ornate carvings adorned almost each corner of the rostrum. It was painted similar to the one in Tengkera Mosque, in gold, red and shellac, but the carving style is relatively modest. The window frame at Kampung Hulu Mosque is also decorated with wood carvings like in Tengkera Mosque but with different floral motif (see visual 28).

Visual 29 shows the classic black decorative ceiling light, as classic as its age and its era. According to the mosque authorities, the decorative light was a gift from the British government and said to be made during the Victorian era. The light was then modified by making it electric powered light.

A donation box which was a gift from Dutch government is tied at the main pillar of the Kampung Hulu Mosque. The donation box was made of copper, thus it is pretty heavy. Mosque goers will put the money inside the box as a donation. A copper engraving decorates the transom-like panel of the main door. This arabic calligraphy copper engraving is also very attractive with pretty classic deep red background with impressive bas-relief .

Upon entering the front door leading to the entrance of the prayer area, we can see a pair of copper cannon placed near the stairs leading to the verandah (see visual 32). According to the mosque authorities, the cannon was a gift from Dutch government. The cannon is now a symbolic historical artifact gracing the Kampung Hulu Mosque. In fact it is one of the oldest mosques in Malaysia and also in Southeast Asia still actively used and is often visited by countless mosque goers from within and outside Malacca.

Another aesthetic form found in the oldest mosque is 'Beduk' (drum) which is located at the front gate of the mosque entrance (see visual 33). The drum is placed within a special structure with stairs leading to it. In the olden days, the drum is used as an indication for a call of prayer. Beduk was made of wood and goat or cow hide, the difference from the normal drum is the size which is bigger and longer. Because of its size, it is usually placed horizontally with a wooden support. Most of the old mosques in Malacca are equipped with Beduk .

The next study was on Kampung Keling Mosque not far from Kampung Hulu Mosque. The mosque also has uniqueness and aesthetic of its own. If we look closely, the ornate floral carving in the mosque is unique and richer; the interior design bears influence from India. This mosque is also visited by many foreign tourists as it is located on the same street that locates the old Hindu and Buddhist temp

At the verandah area, a similar gold and silver decorative cast iron found in the previous two mosques can be seen. The difference is in the motifs (see visual 34). There is also a wood carving painted gold and red on the fanlight of the main entrance door. In contrast to the decorative motifs cast iron in Tengkera Mosque, the exquisite decorative motifs in this mosque were made of wood (see visual 35). The decorative calligraphy art in Kampung Hulu Mosque was made of copper. Although the form and shape of the three mosques is almost similar, the decorative motif that decorates every corner of the mosques is different.

The atmosphere is different in Kampung Keling Mosque prayer area. Unlike the two previous mosques, Kampung Keling Mosque has its own uniqueness where we can see six pillars in front of the rostrum separating the prayer area. Interestingly, the decorative motifs and patterns on the six pillars were influenced by wood carving from India. The choice of color can also be said to be similar to most silver and gold carved objects.

There is a donation box tied at the pillar at the back area of the rostrum, similar to the one in Kampung Hulu Mosque and according to mosque authorities, the box is as old as Kampung Hulu Mosque (see visual 36).

The wood carving on the fanlight of the door inside the prayer area was painted silver with red background and at the centre is Arabic calligraphy surrounded by ornate carving in gold as we can see in visual 37 . A decorative ceiling light hung inside the prayer room looks similar like the one in Kampung Hulu Mosque.

Visual 39 shows the carvings on the six pillars that acts as a divider to the prayer area. If we look closer, the carving pattern and style shows influences from India. This relates to the time of the construction where merchants from India who built the mosque had incorporate elements of art from their country to the carving.

The uniqueness of the mosque can be seen through the rostrum which is almost similar to the ones in Kampung Hulu Mosque and Tengkera Mosque, but the decorative motifs on the rostrum at Kampung Keling Mosque is quite different from the other two. If we look closer, the carving pattern is simpler but the choice of color is still the same with the other two mosques.

On the ceiling, a wood carving with floral motifs decorates the top end of each main pillar. This carving doesn't exist in the previous two mosques (see Visual 42). At the verandah we can see ceramics tiles with floral motifs decorating parts of the exterior wall (see visual 43).

There is a water fountain in the middle of the ablution pool (see visual 44). The three old mosques have water fountain built in the middle of the ablution pool, but the decorative motifs of the water fountain in Kampung Keling Mosque is more exquisite in comparison. 


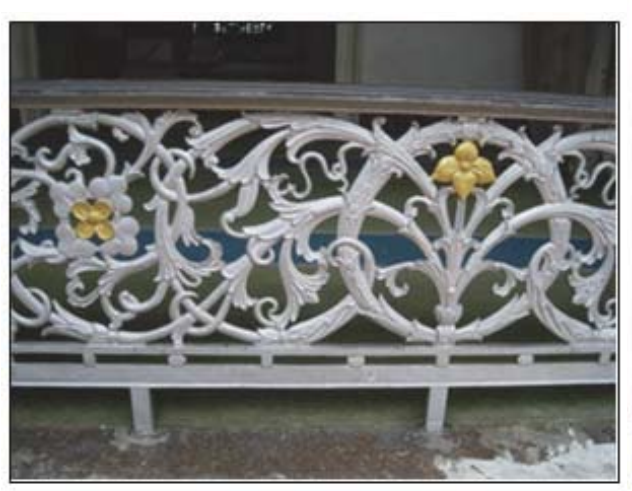

Visual 25: Ornate floral motifs adorned the small fence at the mosque verandah

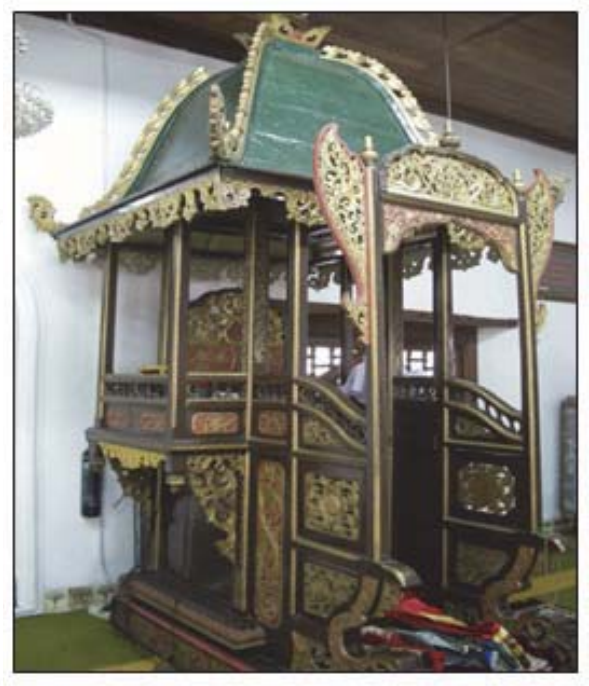

Visual 26: The rostrum at Kampung Hulu Mosque

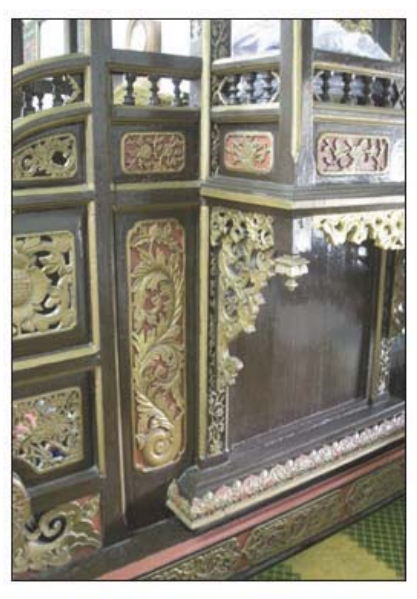

Visual 27: Carving style on the rostrum at Kampung Hulu Mosque

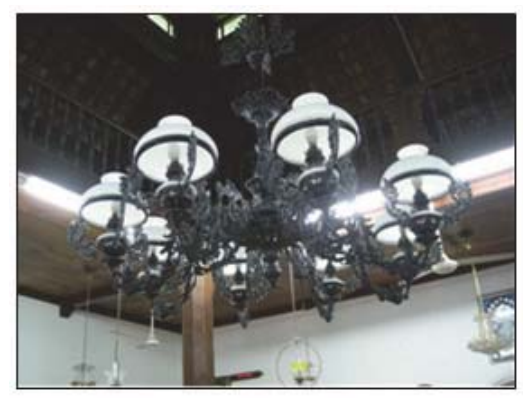

Visual 29: Decorative light hung from the ceiling at Kampung Hulu Mosque

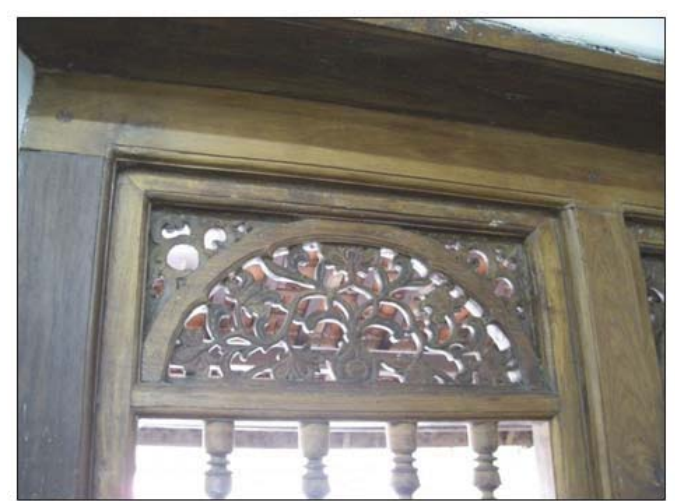

Visual 28: Carving of the window frame at Kampung Hulu Mosque

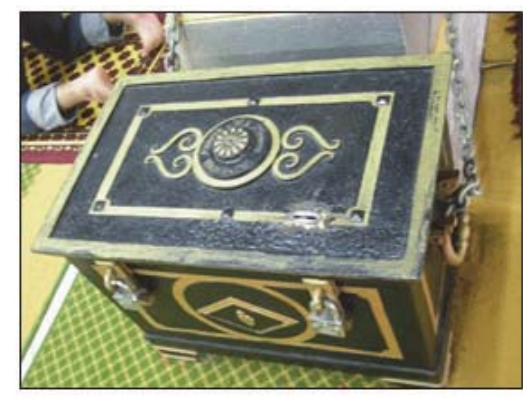

Visual 30: Donation box in Kampung Hulu Mosque 


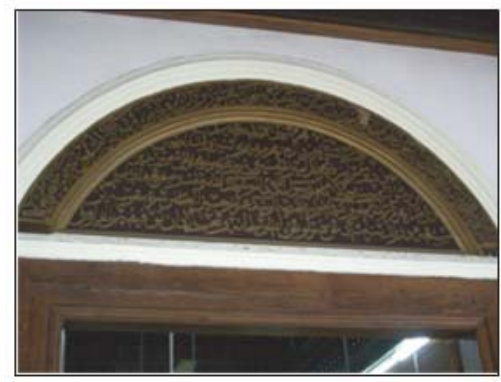

Visual 31: Arabic calligraphy carving with Quranic verses decorates the transom-like panel of the main door at the mosque

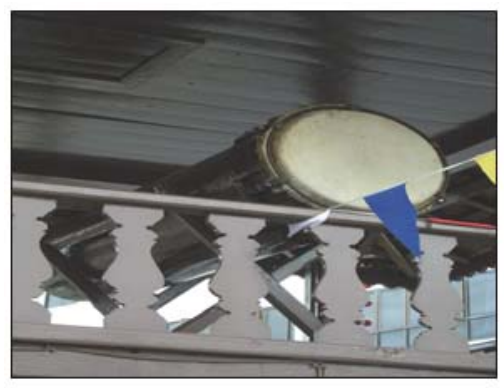

Visual 33: 'Beduk' (drum) previously used for a call of prayer

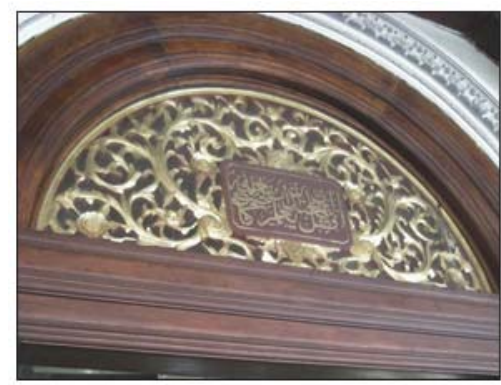

Visual 35: Beautiful omate wood carving on the fanlight of the main entrance door leading to prayer area at Kampung Keling Mosque

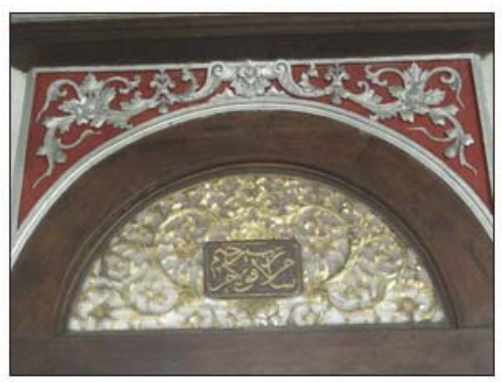

Visual 37: Carving on the fanlight of the door leading to the prayer area

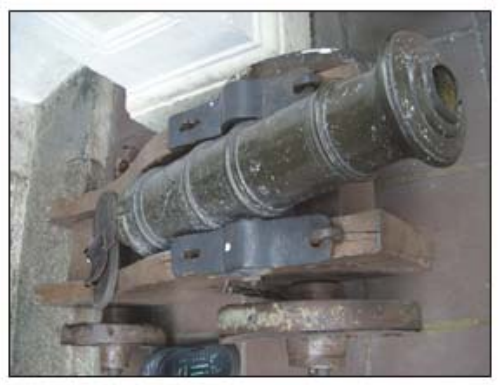

Visual 32: Cannonmade of copper from Dutch colonial era is now a decorative piece at the front foyer leading to the verandah of Kampung Hulu Mosque

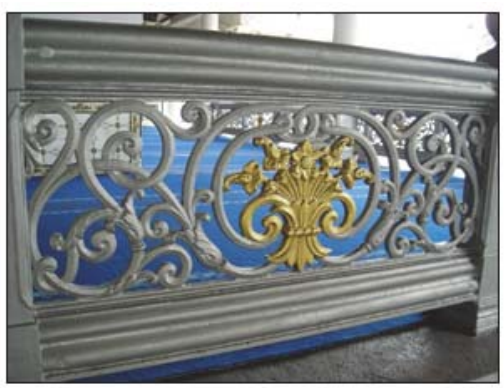

Visual 34: Carving with decorative motifs found at the verandah of Kampung Keling Mosque

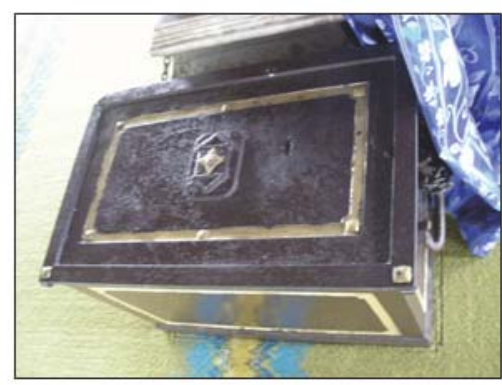

Visual 36: Donation box tied at the main pillar of Kampung Keling Mosque

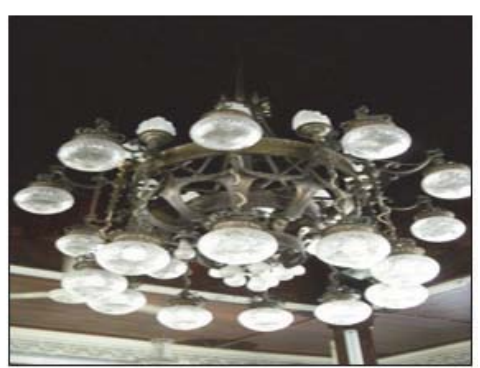

Visual 38: Decorative ceiling light hung inside the prayer room at Kampung Keling Mosque 


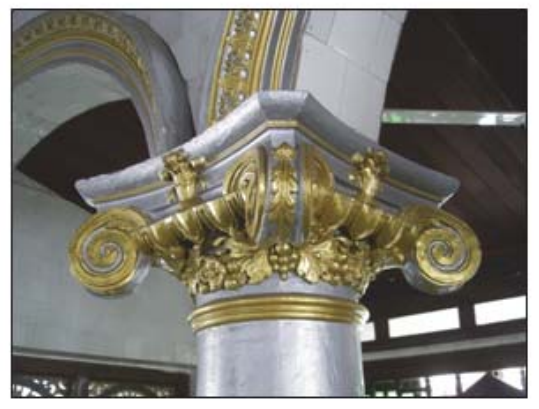

Visual 39: Carving on the six pillars at Kampung Keling Mosque

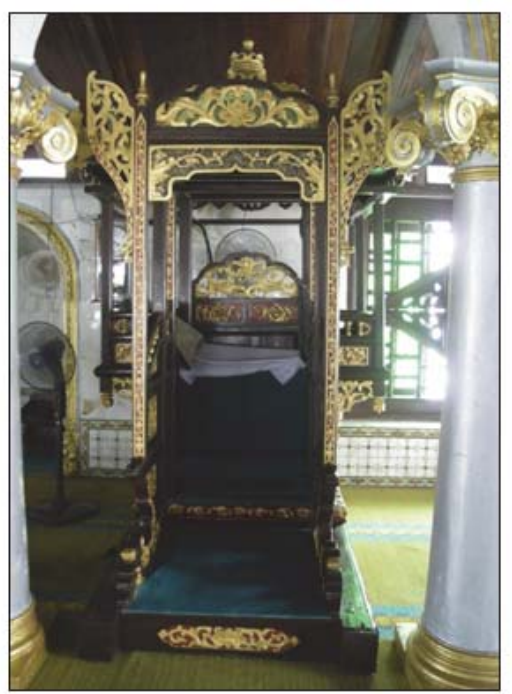

Visual 40: The rostrum at Kampung Keling Mosque

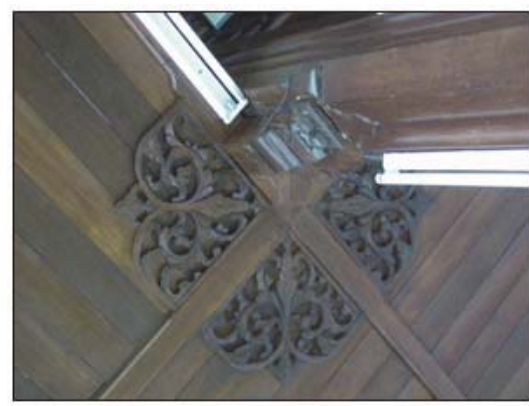

Visual 42: Omate carvings on the ceiling that decorates each angle of the main pillar

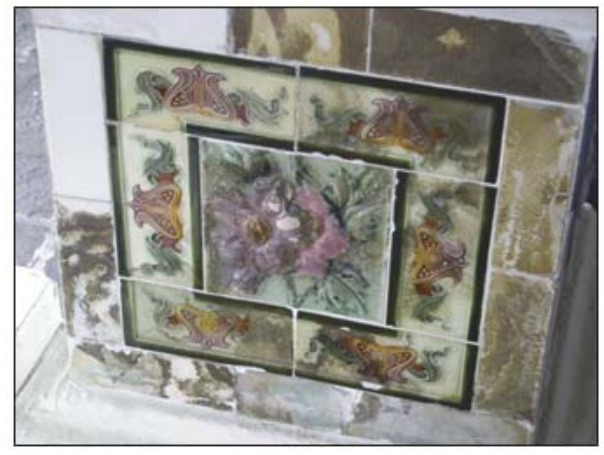

Visual 43: Vintage ceramics tiles beautify the verandah of the mosque

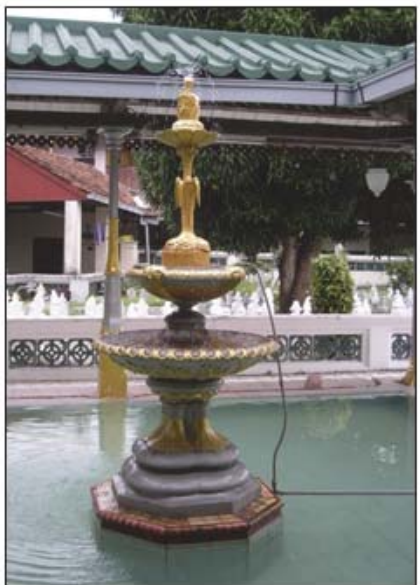

Visual 44: A water fountain in the middle of the ablution pool 


\section{The History of Kampung Keling Mosque}

Aesthetics is a borderless huge scope to be debated or interpreted by art observers who need to express an opinion on the beauty of art. The aesthetic beauty and uniqueness of the three old mosques in Malacca is heavily influenced by the diversity of combinational design influence from China, India and Malay Archipelago. This uniqueness is rarely found in other mosques outside Malacca. Apart from its rich heritage trails, Malacca was known as a center of human civilization and a prominent center for dissemination of Islam in Southeast Asia during its glory years, thus its art is unique and diversified. In the truest sense, the art is not only covering the aspect of art but also in the culture mixing of a multicultural society. To that end, Malacca possesses strength in art with unique aesthetic of its own.

\section{References}

Abdul Halim Nasir, (1995). Seni Bina Masjid di Dunia Melayu-Nusantara. Universiti Kebangsaan Malaysia. Bangi Selangor.

Abdullah Mohamed, (1978). Bentuk-bentuk Bangunan Masjid Kunci Memahami Kebudayaan Melayu. Kementerian Kebudayaan, Belia dan Sukan Malaysia.

Buyong Adil, (19730. Sejarah Melaka dalam Zaman Kerajaan Melayu. Imprint Kuala Lumpur : Dewan Bahasa dan Pustaka

Ed. Martin Frishman and Hasan-Uddin Khan, (1994). The Mosque: History, Architectural Development and Regional Diversity. London: Thames and Hudson, 237-238.

Hamdzun Haron, 2013. Akal Rekaan Pandai Seni Warisan Melayu. Selangor: Institut Alam dan Tamadun Melayu, UKM.

John Hospers, (1969). Introductory Reading In Aesthetics. The Free Press. New York.

Mohamad Tajuddin Mohamad Rasdi, (2000). The Architectural Heritage of the Malay World. Universiti Teknologi Malaysia, Skudai.

Mohd Jamil Mukmin, (2004). Melaka Pusat Peyebaran Islam Di Nusantara. Institut Kajian Sejarah Dan Patriotisme Malaysia (IKSEP)

Sutrisno, Mudji dan Christ Verhaak. (1993). Estetika Filsafat Keindahan . Kanisius, Yogyakarta

Utusan Malaysia, 5 April 2006. Bicara Agama: Masjid tertua Melaka pertahankan seni bina tempatan 